\title{
MODEL PENGEMBANGAN SDM INDUSTRI PERBANKAN SYARIAH PADA ISLAMIC BANKING SCHOOL YOGYAKARTA
}

\author{
Syaparuddin \\ Sekolah Tinggi Agama Islam Negeri (STAIN) Watampone \\ safar_bone@yaboo.co.id
}

\begin{abstract}
This research aims to find out and to explore, describe, explain and map buman resources required by Islamic Banking Industry in Indonesia and the development of human resources in IBS Yogyakarta. This study is a field research using a qualitative approach. The design use qualitative descriptive design which is supported with interview, observation, documentation and library studies in collecting the datas. The datas which were collected, are analysed with descriptive and content analysis. The result shows that human resources required by Islamic Banking Industry in Indonesia, are more than bankers. They have to own multi dimension, competence with integrated sciences. To fulfill this, the development of buman resources in IBS Yogyakarta is desiged with four main competences, so that they get ahead in entering the Islamic banking industry. The competencies are: core competencies, behavior, functional and managerial competence.
\end{abstract}

Keywords: Human Resources, Competence, Islamic Banking.

\begin{abstract}
Abstrak
Penelitian ini bertujuan untuk mengetahui, menjajaki, menguraikan, menerangkan dan memetakan kompetensi SDM yang dibutubkan industri perbankan syariab di Indonesia dan pengembangan SDM di IBS Yogyakarta. Berdasarkan pada tujuan ini, maka penelitian ini adalab penelitian lapangan dengan menggunakan pendekatan kualitatif. Sedangkan desain yang digunakan adalah desain deskriptif kualitatif yang didukung dengan wawancara, observasi, dokumentasi dan studi pustaka dalam mengumpulkan data-data. Data-data yang telah dikumpulkan dianalisis dengan analisis deskriptif dan analisis konten. Hasilnya menunjukan babwa SDM ekonomi syariab yang dibutubkan pada industri perbankan syariah di Indonesia, adalab SDM dengan kemampuan lebih dari sekedar bankir. SDM yang multi dimensi, yang memiliki kompetensi lintas keilmuan. Untuk memenubi hal ini, maka pengembangan SDM di IBS Yogyakarta didesain dengan empat kompetensi utama, agar mereka bisa unggul dalam memasuki industri perbankan syariah, kompetensi tersebut yaitu: kompetensi inti, perilaku, fungsional dan manajerial.
\end{abstract}

Kata Kunci: SDM, Kompetensi, Perbankan Syariah.

Vol. 8, No. 2, Desember 2014 


\section{Pendahuluan}

Konsep perbankan syariah yang pada mulanya hanya merupakan diskusi teoritis, kini telah menjadi realitas faktual yang tumbuh dan berkembang. Bahkan saat ini, industri perbankan syariah telah bertrasformasi dari hanya sekedar lembaga keuangan alternatif dengan sistem syariah menjadi lembaga keuangan yang mampu memainkan peranannya dalam ekonomi global. Hal ini ditunjukkan adanya perkembangan secara signifikan yang dialami oleh perbankan syariah. Menurut laporan tahunan IDB (IDB, 2008: 4) bahwa industri ini tumbuh lebih dari 15\% per tahun dengan jumlah institusi lebih dari 300 yang tersebar di lebih 75 negara dengan perkiraan total aset 500 miliar dollar atau sekitar Rp. 4.600 triliun. Dengan kata lain, pasar yang sudah dicapai sekarang baru sekitar 10\%. Ini menunjukkan bahwa industri ini masih menjanjikan perkembangan yang luar biasa di masa akan datang.

Meskipun perbankan syariah berkembang cukup signifikan, namun masih dihadapkan oleh berbagai macam tantangan. Hal ini diungkapkan oleh Yuslam Fauzi (Fauzi, 2009: 9) dengan mengatakan bahwa tantangan yang dihadapi oleh perbankan syariah antara lain: (1) Customers. Terjadi perubahan orientasi konsumen dari religion oriented ke return oriented dengan ekpektasi yang sama dengan nasabah konvensional. (2) Network. Cakupan wilayah dan teknologi masih terbatas. (3) Debitur. Sulit dalam mendapatkan debitur yang baik dan bankable. (4) Resiko. Resiko usaha sektor riil masih tinggi. (5) Pricing. Persaingan pricing antar bank syariah (bahkan dengan bank konvensional) semakin tajam. (6) CAR. CAR bank syariah sangat terbatas dengan adanya kebijakan Arsitektur Perbankan Indonesia, karena itu ia harus memperkuat modal. (7) Man Power. Sumber daya manusia yang dimiliki oleh bank syariah masih sangat terbatas.

Keterbatasan SDM ekonomi syariah sekarang ini, telah menjadi polemik yang tengah dihadapi oleh perbankan syariah. Tidak hanya persoalan kuantitas saja tapi juga secara kualitas menjadi suatu persoalan yang perlu dibenahi. Hasil riset yang dilakukan oleh FE UI (Tim Peneliti FE UI, 2003: 53) menunjukan bahwa lebih dari 90\% SDM bank syariah saat ini tidak memiliki 
latar belakang pendidikan ekonomi syariah. Sedangkan penyajian Outlook Perbankan Syariah 2009 (Tim BPS BI, 2009: 62) menunjukkan bahwa di antara kendala percepatan market share (5\%) perbankan syariah adalah faktor SDM, baik dari sisi minimnya jumlah SDM perbankan syariah maupun kualitasnya yang masih rendah. Sementara yang disebutkan dalam Majalah Sharing (Anonymous, 2009: 24) bahwa saat ini baru 10\% SDM yang memiliki latar belakang syariah yang bekerja di industri perbankan syariah dan 90\% adalah berlatar belakang dari konvensional yang dikarbit melalui short course perbankan syariah.

Padahal kebutuhan akan kuantitas SDM ekonomi syariah sangatlah besar. Hal ini ditegaskan oleh Direktur Direktorat Perbankan Syariah BI (Anonymous, 2009: 25) bahwa dalam 4-5 tahun ke depan dibutuhkan 10 ribu SDM untuk mengisi industri perbankan syariah di Indonesia. Sementara menurut data Direktorat Perbankan Syariah BI (Direktorat Perbankan Syariah BI, 2010: 72) bahwa industri perbankan syariah di Indonesia membutuhkan sekitar 14 ribu SDM, seiring dengan peningkatan pertumbuhan jumlah kantor perbankan syariah yang rata-rata peningkatannya dalam 5 tahun terakhir sebesar 23,2\%. Namun yang menjadi kekhawatiran menurut Farisal, adalah di saat meningkatnya industri perbankan syariah, justru faktor SDM-nya yang akan merosot. Perbankan syariah berlomba-lomba membuka jaringan secara besarbesaran namun tidak diiringi dengan persiapan SDM yang berkualitas terlebih dahulu. Farisal (Farisal, 2010: 55) menjelaskan bahwa kekhawatiran ini sangat wajar sekali muncul, apabila langkah manajemen perbankan syariah yang dengan serba instan membuka jaringan secara tergesa-gesa, merekrut dan mendidik SDM-nya secara kurang cermat dan kurang sabar, serta tidak berorientasi pada kualitas dan kompetensi, maka dengan segala konsekuensi harus dihadapi kemudian apabila perbankan syariah menemui berbagai macam masalah, seperti manipulasi informasi, hadiah dalam rangka pencarian pembiayaan, merubah akad secara sepihak, bahkan memberikan pelayanan yang rendah mutunya.

Oleh karena itu, lembaga pendidikan dari berbagai tingkatan (strata) sangat dibutuhkan untuk menyediakan SDM ekonomi syariah yang ahli secara teoritis dan praktis. Pada masa mendatang, 
tidak tepat jika lembaga-lembaga keuangan syari'ah, bank dan non bank dikelola oleh para muallaf, "mengislamkan" orang yang semula berpikir kapitalis. Karena itu, tugas ini menjadi salah satu tanggungjawab lembaga pendidikan tinggi dalam mencetak SDMSDM yang handal dalam bidang ekonomi syariah.

Salah satu lembaga pendidikan tinggi yang melakukan tugas ini adalah Islamic Banking School (IBS) STEI Yogyakarta, dan ia cukup berhasil dalam melaksanakan tugasnya tersebut. Hal ini ditunjukkan oleh pengalaman para alumninya, di mana mereka pada umumnya cukup sukses diterima berkeja di industri perbankan dan keuangan syariah lainnya karena mereka telah memiliki kompetensi yang dibutuhkan industri perbankan dan keuangan syariah tersebut. Hasil survei internal yang dilakukan oleh IBS STEI Yogyakarta (Tim IBS Yogyakarta, 2011) menunjukan bahwa aluminya pada tahun 2011, 70\% bekerja pada bank dan lembaga keuangan, 21\% menjadi PNS (PEMDA dan BAZDA), 6\% menjadi tenaga akademik (Perguruan Tinggi), dan 3\% menjadi wiraswasta. Selain itu, mereka juga memiliki tingkat agresivitas dalam bekerja, kemampuan berkomunikasi, kemampuan bekerja sama, ulet dan tidak putus asa.

Berdasarkan penjelasan tersebut di atas, maka rumusan masalah yang dapat ditarik pada penelitian ini, yaitu: SDM seperti apa yang dibutuhkan oleh industri perbankan syariah di Indonesia, dan bagaimana IBS STEI Yogyakarta mengembangkan SDM yang dibutuhkan oleh industri perbankan syariah tersebut?

\section{Teori Human Capital}

Human Capital dapat didefenisikan sebagai pengetahuan, skill, sikap bakat, and faktor-faktor lain yang dapat menghasilkan sesuatu. Skill menggambarkan kemampuan individu dalam menghasilkan sesuatu. Menurut Blundell, Human Capital memiliki dua komponen utama yang sangat saling melengkapi satu sama lain, yaitu: kemampuan awal (boleh jadi diperoleh atau merupakan bawaan) dan keterampilan yang diperoleh melalui pendidikan formal atau melalui magang (Fleischhauer, 2007: 4). Jadi Human Capital berbeda dengan aset-aset lain karena ia dapat memberikan hasil sesuai dengan suplai tenaga kerja yang dimiliki setiap individu. 
Istilah Human Capital dalam literatur ekonomi modern pertama kali digunakan oleh Schultz pada tahun 1961. Ia menganggap bahwa pengeluaran untuk Human Capital merupakan investasi, bukan sebagai konsumsi. Pada tahun yang sama, Weisbrod mengembangkan kerangka konseptual pertama untuk mengestimasi nilai aset-aset dalam bentuk Human Capital. Nilai-nilai Human Capital merupakan aset produktif yang dikaitkan dengan jenis kelamin, umur, stok Human Capital dan lain-lain. Present Value (nilai sekarang) bagi seorang individu berapa pun umurnya merupakan jumlah pendapatan yang diharapakan di masa mendatang dengan nilai sekarang, Yt (sama dengan nilai produktivitas):

$$
V(a)=\sum_{t=\infty}^{\infty} \frac{P_{a t}}{(1+r)^{t-a}} Y_{t}
$$

Pat menggambarkan probabiliti umur seseorang (a) yang hidup dengan umur (t) dan (r) adalah discount rate. Secara umum, ada dua metode dalam menentukan nilai Human Capital, yaitu dengan menjumlahkan biaya produksi (input-based), dan dengan mempertimbangkan pendapatan yang dimodali (output-based) (Fleischhauer, 2007: 4).

Becker and Mincer dari the Chicago school merupakan orang yang pertama mengaplikasi teori Human Capital dalam ekonomi. Pada pendekatan orisinilnya, Becker mengembangkan model investasi individu pada Human Capital. Menurutnya, Human Capital sama dengan "physical means of production" (sarana produksi fisik). Lebih lanjut dikatakan bahwa investasi pada Human Capital merupakan "all activities that influence future real income through the embedding of resources in people" (seluruh aktivitas yang mempengaruhi perdapatan riil di masa mendatang dengan mengaitkan sumber daya yang ada pada orang). Investasi Human Capital berarti melakukan pengeluaran untuk pendidikan, training, kesehatan, informasi dan mobilitas tenaga kerja (Fleischhauer, 2007: 4).

Dari penjelasan tersebut di atas dapat disimpulkan bahwa teori Human Capital merupakan teori ekonomi masa kini yang 
datang dari kesadaran bahwa ilmu pengetahuan dan keterampilan seorang individu merupakan suatu bentuk modal perusahaan. Jadi pendidikan mempunyai nilai ekonomis yang harus diperhitungkan oleh perusahaan. Postulat dalam teori Human Capital (Lieras, 2004: 9-10) menyatakan bahwa pendidikan membantu SDM untuk mendapatkan kualitas yang prospektif, selain itu produktivitas SDM juga ditentukan oleh kemampuan dan faktor-faktor lainnya.

Sejalan dengan teori tersebut, Green (Green, 2000: 8) menyatakan bahwa pendidikan tinggi mempunyai misi utama dalam menyediakan kebutuhan tenaga kerja terlatih untuk perekonomian nasional dan pembangunan sosial. Salah satu di antaranya terkait dengan penyediaan lulusan untuk memenuhi kebutuhan SDM pada perusahaan bisnis, industri dan sektor jasa pelayanan.

Dengan demikian, SDM yang memiliki nilai ekonomis, yaitu SDM yang berkompeten, yakni SDM yang memiliki atribut-atribut pribadi (ability dan motivation) (Amalia, 2009: 32) yang menyatu dalam kemampuannya, dan untuk memperolehnya harus melalui pendidikan dan pengalaman.

\section{Manajemen SDM Berbasis Kompetensi}

Kompetensi merupakan kemampuan performa individu dalam melaksanakan suatu tugas yang ditentukan oleh kombinasi dua unsur, yaitu (1) ability, meliputi: keterampilan, pengetahuan, kreativitas, dan intelektual, dan (2) motivation, meliputi: nilai dan keyakinan, kepercayaan diri, kepuasan dan kenyamanan (Amalia, 2009: 32). Kompetensi pada suatu organisasi akan menjadi landasan bagi pengelolaan SDM dalam sebuah perusahaan. Kompetensi akan menjadi kunci untuk penerapan strategi organisasi melalui orangorang yang ada dalam organisasi. Penerapan pengelolaan SDM berbasis kompetensi akan memungkinkan adanya pendekatan yang terintegrasi dalam sistem manajemen SDM (Kertajaya, 2009: 62).

Kompetensi yang terintegrasi dan terfokus pada kinerja yang superior dapat mempengaruhi setiap sistem manajemen SDM yang lain, hal ini dapat dilihat sebagai berikut (Darma, 2002: 36-40): Pertama, Rekrutmen dan Seleksi. Untuk dapat merekrut karyawan yang tepat pada sebuah organisasi/perusahaan, diperlukan adanya 
persyaratan kompetensi yang jelas pada setiap jabatan yang akan direkrut atau diseleksi. Di sisi lain pemilihan metode assesment/ seleksi yang tepat juga akan mampu memilih karyawan sesuai dengan kompetensi yang dibutuhkan. Menghidari kesalahan dalam merekrut calon karyawan berarti mengurangi biaya yang tidak perlu akibat kesalahan dalam proses rekrutmen. Sebagai tambahan bahwa ketepatan merekrut karyawan akan menentukan keberhasilan organisasi.

Kedua, Pelatihan dan Pengembangan. Pelatihan dan pengembangan yang berdasarkan kompetensi akan dapat membantu organisasi untuk lebih fokus pada pengembangan kompetensi yang dibutuhkan organisasi dalam meningkatkan kinerja. Selain itu, penerapan pelatihan dan pengembangan karyawan berbasis kompetensi juga akan membantu organisasi dalam menetapkan program pelatihan dan pengembangan yang lebih terarah.

Ketiga, Pembinaan Karir. Dengan menggunakan sistem kompetensi, perusahaan akan lebih mudah dalam mengidentifikasi dan mengembangkan karyawan yang memiliki kompetensi tinggi. Dengan demikian pengambilan keputusan dan pelaksanaan promosi atau mutasi akan lebih tepat dan mempunyai dasar yang kuat. Hal tersebut sangat penting karena kejelasan pembinaan karir diyakini akan meningkatkan motivasi karyawan dalam meningkatkan kinerja.

Keempat, Manajemen Kinerja. Sistem pengelolaan SDM berbasis kompetensi akan membantu organisasi untuk fokus pada pengembangan kompetensi oragnisasi/perusahaan sebagai pembeda daya saing dari organisasi lain. Secara keseluruhan akan meningkatkan kinerja organisasi, karena kompetensi yang dikembangkan dapat memprediksi kinerja organisasi.

Kelima, Remunerasi. Memperjelas sistem penghargaan dan remunirasi dengan memberikan imbalan bagi kompetensi yang ditunjukkan oleh anggota organisasi, akan mampu memotivasi karyawan untuk meningkatkan kompetensi dan kinerjanya. Selain itu memperjelas kaitan antara imbalan atau penghargaan dengan kinerja, dimana penghargaan yang lebih baik akan diterima oleh orang yang menunjukkan kompetensi dan kinerja yang lebih baik. 
Karena itu, pengembangan SDM ekonomi syariah yang berbasis kompetensi harus dilakukan agar dapat memberikan hasil yang sesuai dengan tujuan dan sasaran industri perbankan syariah dengan standar kinerja yang telah ditetapkannya. Kompetensi tersebut tentunya menyangkut kewenangan setiap individu untuk melakukan tugas atau mengambil keputusan sesuai dengan perannya pada bank syariah yang relevan dengan keahlian, pengetahuan, dan kemampuan yang dimilikinya. Kompetensi yang dimiliki karyawan secara individual harus mampu mendukung setiap perubahan yang dilakukan manajemen bank syariah. Dengan kata lain, kompetensi yang dimiliki individu dapat mendukung sistem kerja bank syariah berdasarkan tim. Tanpa memiliki orang-orang yang berkompeten, sulit bagi bank syariah untuk mencapai tujuannya.

\section{Perguruan Tinggi sebagai Penyedia SDM}

Perguruan tinggi sebagai satuan pendidikan yang mempersiapkan dan mencetak SDM dituntut dapat mempersiapkan diri dan mampu mengantisipasi kondisi globalisasi (Tilaar, 2009: 94). Karena itu, perguruan tinggi diharapkan mampu mempersiapkan SDM yang unggul dan dapat memegang peran penting dalam bidang ekonomi, khususnya dalam bidang keuangan dan perbankan syariah pada era globalisasi.

Hal tersebut di atas didasarkan pada fakta bahwa pada tataran teoritis dan konseptual, SDM ekonomi syariah dirasa masih sangat kurang. Figur seperti ini benar-benar langka bukan saja bagi masyarakat Islam di Indonesia melainkan juga di banyak negara termasuk negara lain yang perkembangan ekonomi Islamnya cukup pesat (Nazir, 2004: 68). Kebanyakan SDM lembaga keuangan syariah saat ini adalah mereka yang fasih berbicara tentang ilmu ekonomi keuangan kontemporer, tetapi awam dalam ushul fikih atau fikihmuamalah. Sebaliknya banyak pakar yang mahir dalam fikihdan ushul fikih tetapi kurang memahami Ilmu Ekonomi dan Keuangan.

Di sinilah letak tanggung jawab perguruan tinggi dalam melahirkan SDM ekonomi syariah yang kompeten dan memadai, serta memiliki integritas tinggi. SDM ekonomi syari'ah, tidak boleh 
lagi bersifat karbitan seperti yang banyak terjadi selama ini. Akan tetapi, perguruan tinggi pada umumnya menghadapi sejumlah kendala dalam upaya mengembangkan kualitas. Kendala itu, antara lain (Noor, 2011): (1) keterbatasan ahli ekonomi dan keuangan syariah, yang menguasai secara komprehensif ilmu ekonomi, keuangan sekaligus ilmu syariah, (2) keterbatasan dari segi kurikulum pengajaran, kurikulum belum berbasis kepada kompetensi, (3) belum ada linkage antara lembaga pendidikan dengan lembaga keuangan syariah, dan (4) keterbatasan dana dan SDM sehingga riset dan laboratorium penelitian di bidang ilmu ekonomi dan keuangan syariah masih terbatas.

Karena itu perlu dilakukan redesign tentang institusi kependidikan di Indonesia terutama di fakultas/jurusan/prodi ekonomi dan syariah, agar dapat menghasilkan sarjana yang mempunyai skills ekonomi syari'ah dan memiliki budi pekerti yang sesuai dengan syariah Islam dan applicable di sektor ekonomi.

Lembaga pendidikan adalah institusi yang bertanggung jawab dalam menghasilkanSDM yang berkualitas. Jadi, dalam pengembangan pendidikan ekonomi syariah di masa yang akan datang setidaknya ada lima aspek yang perlu mendapat perhatian serius, yaitu (Amalia, 2010: 172-175): Pertama, Set kurikulum yang tepat; mengkombinasikan mata kuliah yang memberikan pengetahuan profesionalitas ekonomi syariah serta nilai-nilai moral (akidah \& akhlak). Kedua, Tersedia sarana dan fasilitas belajar yang memadai; matrikulasi bahasa, perpustakaan (literatur lengkap), laboratorium (bank, akuntansi dll). Ketiga, Staf pengajar yang kompeten dan berkualitas. Keempat, Buku teks yang memadai (perpustakaan yang menyediakan buku dan litaratur ekonomi Islam). Kelima, Program pendukung seperti; magang, on-job training dan sebagainya.

Dalam membentuk SDM unggul, pemerintah memberikan otonomi seluas-luasnya kepada setiap perguruan tinggi untuk mengatur sendiri kurikulum setiap program studi yang diselenggarakannya. Oleh karena itu, perguruan tinggi harus mulai terbuka dan memperhatikan SDM yang akan dihasilkannya. Pemberian bekal dalam ilmu pengetahuan, teknologi, keterampilan, dan sikap (attitude), pengembangan diri dan penyiapan mental akan sangat mendukung sekali terhadap terbentuknya manusia unggul yang 
memiliki keseimbangan antara kecerdasan intelektual dan kecerdasan emosional.

\section{Metode Penelitian}

Penelitian ini adalah penelitian lapangan dengan menggunakan pendekatan kualitatif. Sedangkan, desain penelitian yang digunakan adalah desain deskriptif kualitatif, yaitu peneliti bermaksud menjajaki, menguraikan, menerangkan dan memetakan kompetensi SDM yang dibutuhkan industri perbankan syariah di Indonesia serta pengembangan SDM ekonomi syariah yang dilakukan IBS STEI Yogyakarta dalam memenuhi kompetensi tersebut.

Untuk memperoleh data, dilakukan observasi, wawancara, dokumentasi dan penelusuran literatur kepustakaan. Sebagai langkah dalam menganalisisnya, Data-data yang telah diperoleh dan terkumpul, dilakukan kategorisasi kemudian dianalisis. Data-data yang diperoleh dari hasil interview diinventarisir untuk memperoleh gambaran yang jelas dari narasumber. Sedangkan data kualitatif dianalisis dengan cara menganalisa pernyataan kunci, menganalisa dokumen-dokumen dan melakukan pemetaan kompetensi SDM ekonomi syariah dan pengembanganya di IBS Yogyakarta.

\section{Hasil Penelitian}

Salah satu upaya konkrit yang dilakukan Bank Indonesia dalam mengembangkan perbankan syariah di Indonesia adalah merumuskan sebuah startegi, yang meliputi aspek-aspek, yaitu: Penetapan visi sebagai industri perbankan syariah terkemuka di ASEAN, pembentukan citra baru perbankan syariah nasional yang bersifat inklusif dan universal, pemetaan pasar secara lebih akurat, pengembangan produk yang lebih beragam, peningkatan layanan, serta strategi komunikasi baru yang memposisikan perbankan syariah lebih dari sekedar bank (www.bi.go.id, 2012).

Dalam mengimplemenatsikan strategi tersebut, berbagai program konkrit akan dilakukan, antara lain adalah sebagai berikut (www.bi.go.id, 2012): Pertama, menerapkan visi baru pengembangan perbankan syariah pada fase I tahun 2008 membangun pemahaman perbankan syariah sebagai Beyond Banking, dengan 
pencapaian target asset sebesar Rp.50 triliun dan pertumbuhan industri sebesar 40\%, fase II tahun 2009 menjadikan perbankan syariah Indonesia sebagai perbankan syariah paling atraktif di ASEAN, dengan pencapaian target asset sebesar Rp.87 triliun dan pertumbuhan industri sebesar 75\%. Fase III tahun 2010 menjadikan perbankan syariah Indonesia sebagai perbankan syariah terkemuka di ASEAN, dengan pencapaian target asset sebesar Rp.124 triliun dan pertumbuhan industri sebesar $81 \%$.

Kedua, program pencitraan baru perbankan syariah yang meliputi aspek positioning, differentiation, dan branding. Positioning baru bank syariah sebagai perbankan yang saling menguntungkan kedua belah pihak, aspek diferensiasi dengan keunggulan kompetitif dengan produk dan skema yang beragam, transparans, kompeten dalam keuangan dan beretika, teknologi informasi yang selalu $u p$ date dan user friendly, serta adanya ahli investasi keuangan syariah yang memadai. Sedangkan pada aspek branding adalah "bank syariah lebih dari sekedar bank atau beyond banking".

Ketiga, program pemetaan baru secara lebih akurat terhadap potensi pasar perbankan syariah yang secara umum mengarahkan pelayanan jasa bank syariah sebagai layanan universal atau bank bagi semua lapisan masyarakat dan semua segmen sesuai dengan strategi masing-masing bank syariah.

Keempat, program pengembangan produk yang diarahkan kepada variasi produk yang beragam yang didukung oleh keunikan value yang ditawarkan (saling menguntungkan) dan dukungan jaringan kantor yang luas dan penggunaan standar nama produk yang mudah dipahami.

Kelima, program peningkatan kualitas layanan yang didukung oleh SDM yang kompeten dan penyediaan teknologi informasi yang mampu memenuhi kebutuhan dan kepuasan nasabah serta mampu mengkomunikasikan produk dan jasa bank syariah kepada nasabah secara benar dan jelas, dengan tetap memenuhi prinsip syariah; dan

Keenam, program sosialisasi dan edukasi masyarakat secara lebih luas dan efisien melalui berbagai sarana komunikasi langsung, maupun tidak langsung (media cetak, elektronik, online/web-site), 
yang bertujuan untuk memberikan pemahaman tentang kemanfaatan produk serta jasa perbankan syariah yang dapat dimanfaatkan oleh masyarakat.

Strategi tersebut di atas mensiratkan kebutuhan akan kualifikasi SDM yang multi keilmuan dan multi dimensi untuk menjamin keunggulan khas perbankan syariah. Kualifikasi SDM tersebut menurut Muhamad (hasil wawancara, 2012), yaitu: (1) SDM yang mampu berkedudukan sebagai invesment manager. Artinya, ia paham betul perkembangan dari berbagai sektor industri perbankan syariah sehingga nantinya ia bisa memilih dan memilah investasi mana yang efektif dan profitable untuk dibiayai secara syariah. Jika demikian adanya, maka bank akan mampu menghasilkan profit yang optimal dan juga dapat memberikan nisbah bagi hasil yang memuaskan bagi nasabah penyimpan. Jadi, ia harus kuat pada sisi invesment manajer itu. (2) Terkait dengan invesment manajer, dibutuhkan kualifikasi: (i) SDM yang bisa mengelola dana masyarakat dalam berbagai macam bentuk profit, (ii) SDM yang kreatif dan inovatif dalam mengembangkan produkproduk baru yang sesuai dengan kebutuhan masyarakat, bukan mengikuti apa yang terjadi di konvensional, sehingga produknya berbeda, tidak sekedar menjiblak konvensional lalu kemudian dihayati yang dikenal dengan istilah islamisasi. (3) SDM yang expert in finance and banking. Artinya, ia harus memiliki pengetahuan secara detail tentang instrumen keuangan dan perbankan, dan harapannya juga bisa melakukan inovasi-inovasi yang cerdas. Karena itu, bagi seorang expert, proses pembelajaran harus terus dilakukan dalam melakukan inovasi/modifikasi untuk menghasilkan produk yang sesuai dengan prinsip syariah tetapi dengan sofistifikasi yang sama dengan produk-produk lainnya. (4) SDM yang paham syariah muamalat yang terkait dengan keuangan dan perbankan. Artinya, ia harus mampu memberikan keyakinan kepada masyarakat bahwa produk/jasa yang ditawarkannya sesuai dengan etika dan prinsipprinsip syariah, misalnya tidak mengandung unsur spekulatif ataupun tipuan.

Terkait dengan kualifikasi nomor 4 di atas, saat ini bank syariah banyak terbantu dengan hadirnya DPS (Dewan Pengawas Syariah) yang wajib ada di setiap bank syariah. DPS ini adalah 
juga adalah anggota DSN (Dewan Syariah Nasional), yang tugasnya mengawasi operasional sehari-hari bank syariah agar selalu sesuai dengan prinsip-prinsip syariah sehingga menjamin kemanfaatan produk/jasa yang ditawarkan oleh bank syariah bagi kemaslahatan masyarakat seluruhnya.

Namun menurut Muhamad (hasil wawancara, 2012), sebetulnya SDM perbankan syariah itu adalah DPS. Kalau memang sudah demikian adanya, maka bank tidak usah pakai DPS lagi karena pegawainya sudah ahli syariah, sudah tidak susah mengcreat dan mencermati shariab compliancy karena ia sudah mengerti syariah. Lebih lanjut Muhamad mengatakan bahwa pengalamannya menjadi DPS, ia hanya bisa melihat dokumen saja. Misalnya, jika akad itu sudah dibuat, maka dapat dipakai selamanya. Akan tetapi prakteknya di lapangan kadang kala tidak sesuai dengan akad tersebut. Ini kan jadi masalah. Namun, jika SDM-nya sudah paham syariah maka ia akan sangat hati-hati dalam bertindak dan mengambil keputusan karena ia sudah memiliki pengawasan melekat pada dirinya sendiri. Target boleh, tapi kalau tidak bisa terpenuhi, yang oleh SDM ini sudah melakukan ikhtiar dengan maksimal, maka hal tersebut harus diterima apa adanya karena rezeki yang diberikan oleh Allah pada saat itu memang segitu saja. Nah, ini yang sulit diterima oleh para stakeholder. Karena itu pemahaman pada sisi syariah di sini harus kuat.

Terkait dengan kompetensi yang harus dimiliki oleh SDM bank syariah, Muhamad (hasil wawancara, 2012) melakukan survei dan mendapatkan masukan dari para stakeholder dan praktisi bank syariah bahwa SDM yang dibutuhkannya yaitu SDM yang memiliki empat kompetensi utama, yaitu: Pertama, kompetensi inti, yakni perbankan syariah membutuhkan SDM yang memiliki pandangan dan keyakinan yang sesuai dengan visi dan misi perbankan syariah. Kedua, kompetensi perilaku, yakni perbankan syariah membutuhkan SDM yang mampu bertindak efektif, memiliki semangat Islami, fleksibel, dan rasa ingin tahu yang tinggi. Ketiga, kompetensi fungsional, yakni perbankan syariah membutuhkan SDM yang memiliki background dan keahlian dasar ekonomi syariah, operasional perbankan, administrasi keuangan, dan analisis keuangan. Kempat, kompetensi manajerial, yakni perbankan syariah membutuhkan 
SDM yang mampu menjadi team leader, cepat menangkap perubahan dan mampu membangun hubungan dengan yang lain.

Dengan demikian, SDM yang mendukung perbankan syariah bukanlah SDM dengan kompetensi yang marginal pas-pasan. Bahkan sebaliknya. SDM yang dicari dan dibutuhkan oleh bank syariah adalah SDM dengan kemampuan lebih dari sekedar bankir. SDM haruslah SDM yang multi dimensi, yang memiliki kompetensi lintas keilmuan. Ia harus memiliki kompetensi sebagai seorang ahli investasi, sekaligus ahli keuangan dan perbankan, beretika serta memahami sharia compliancy (www.bi.go.id, 2012). Pemenuhan SDM dengan kompetensi lengkap seperti ini harus dilakukan, baik secara kualitatif maupun kuantitatif, melalui proses rekruitmen dan pelatihan. Karena hanya dengan demikian, perbankan syariah mampu melayani nasabah dengan menyajikan solusi yang lebih lengkap sebagai lebih dari sekedar bank.

Dalam merespon hal tersebut di atas, IBS melalui visinya mensiratkan untuk melahirkan SDM ekonomi syariah yang unggul. Untuk mewujudkan hal ini, mereka didesain dengan kompetensi yang dibutuhkan oleh industri perbankan syariah. Dengan demikian, SDM yang dikembangkan di IBS didesain dengan empat kompetensi utama supaya mereka bisa unggul dalam memasuki industri perbankan syariah setelah tamat. Muhamad (hasil wawancara, 2012) menjelaskan bahwa keempat kompetensi utama yang dimaksud, yaitu: kompetensi inti, perilaku, fungsional dan manajerial. Keempat kompetensi inilah yang dibutuhkan oleh industri perbankan syariah sekarang. Lebih lanjut Muhamad menjelaskan bahwa gambaran mengenai model pengembangan SDM di IBS, yang didesain dengan keempat kompetensi tersebut dapat dipetakan berikut ini, yaitu:

Pertama, kompetensi inti. SDM yang dilahirkan (alumni) IBS memiliki kompetensi inti, yakni mereka punya loyalitas, memiliki pandangan dan keyakinan bahwa perbankan syariah itu adalah sesuatu yang baik, memiliki komitmen yang luar bisa terhadap sesuatu yang diperjuangkan. Untuk itu mata kuliah yang sesuai didesain untuk membangun ini semuanya. Misalnya di IBS, bunga bank sudah tidak diperdebatkan lagi bahwa ia diharamkan. Hal ini harus ditanamkan dari awal, karena jika masih dianggap bahwa 
bunga bank diperdebatkan tidak apa-apa, maka ia akan mengambang. Oleh karena itu, harus ada penyamaan persepsi terlebih dahulu, penyamaan persepsi terhadap sesuatu yang diperjuangkan. Artinya, harus kuat di mata kuliah Teologi Ekonomi Islam, Filsafat Ekonomi Islam. Jadi kalau kerja itu adalah ibadah meskipun honornya kecil, maka dia akan konsisten melakukannya karena apa yang diperjuangkannya itu adalah ibadah. Untuk membentuk hal ini, maka didesain mata kuliah yang sesuai.

Kedua, komptensi perilaku. SDM yang dilahirkan IBS memiliki kompetensi perilaku, yakni mereka bisa bertindak efektif, memiliki semangat islami, flexible, rasa ingin tahunya tinggi. Untuk membentuk ini semua dibutuhkan ilmu manajemen yang baik, pendidikan dan ilmu metodologi, dari sisi fikih usul fikihnya harus bagus agar mereka nanti bisa mengembangkan berbagai macam program, melakukan terobosan-terobosan, dan lain-lain.

Ketiga, komptensi fungsional. SDM yang dilahirkan IBS memiliki kompetensi fungsional, yakni mereka memiliki keahlian dasar tentang ekonomi syariah, perbankan syariah, operasional bank syariah, administrasi keuangan. Ini sudah masuk pada wilayah ilmu ekonomi, ekonomi keuangan dan perbankan. Karena itu, kompetensi ini dibentuk dari mata kuliah ilmu-ilmu ekonomi.

Keempat, kompetensi manajerial. SDM yang dilahirkan IBS memiliki kompetensi manajerial, yakni mereka memiliki kemampuan untuk menjadi team leader, cepat menangkap perubahan dan mampu membangun hubungan dengan yang lain. Untuk membentuk ini semua dibutuhkan ilmu manajemen dan kepemimpinan, dan hal ini sangat terkait dengan mata kuliah manajemen dan kewirausahaan. Inti manajerial itu, sebagaimana yang diberikan kepada mahasiswa IBS apakah mereka mudah berubah atau tidak, mampu membangun sesama atau tidak. Karena itu, mereka harus pandai menyesuaikan zaman, melakukan perubahan-perubahan pada dirinya, tidak cooper, jaringan hubungannya itu harus bagus. Lalu didesain mata kuliah yang sesuai untuk mengisinya.

Kendalanya menurut Muhamad (hasil wawancara, 2012), adalah siapa yang mengajar? Kompetensi-kompetensi tersebut di atas sangat tergantung pada siapa yang akan membentuknya, artinya 
dosennya siapa? Di IBS, suatu ketika Tim Manajemen harus tega menyingkirkan dosen, meskipun hal ini sangat sulit dilakukan, apalagi di PT Negeri. Tapi ini suatu realitas yang kita terapkan. Jadi itu adalah resiko yang dihadapi karena dia tidak punya kompetensi yang dibutuhkan. Mata kuliahnya ini, sementara kita sudah melihatnya bahwa lapangan tuntutannya begini, maka mau tidak mau kurikulum harus disesuaikan dengan kebutuhan pasar. Jika mata kuliah yang dikuasai oleh seorang dosen tidak ada lagi, mau tak mau ia harus disingkirkan. Ia bisa mengajar lagi kalau ia mau belajar dan menyesuaikan keadaan yang ada.

Jadi dosen itu dituntut supaya punya sifat flexibilitas, kemauan untuk ingin tahu yang lebih baik dan jangan malu bertanya. Seringkali senioritas itu mempengaruhi perilaku seseorang, maka suka tidak suka terjadilah ancam mengancam. Harus bisa disadari bahwa harus bisa melakukan perubahan yang lebih baik, oleh karena itu apa yang diinginkan harus ada kesepahaman tentang apa yang hendak dibuat. Inti program pendidikan itu adalah apa yang hendak dibikin. Karena itu, bahan dasar yang dibutuhkan adalah input mahasiswa, kurikulum, dan penyesuaian diri dosen. Jika dosennya tidak sesuai dengan keahlian yang dibuat, maka ia harus belajar dulu, kursus, mengikuti program short course, mengikuti program team teaching, TOT dosen, dan lain-lain. Supaya jika terjadi perubahan kurikulum dan perubahan nama mata kuliah betul-betul berubah secara subtansial. Bukan berubah nama tapi isinya sama, bukan seperti ini yang dibutuhkan.

Dengan demikian, hal yang perlu dipersiapkan adalah pembenahan terhadap visi dan misi, yakni mau dibawa ke mana alumni-alumni itu. Setelah itu kurikulumnya, yakni ia harus didesain berdasarkan empat komptensi utama, yaitu kompetensi inti, perilaku, fungsional dan manajerial. Nampaknya hal ini perlu disosialisasikan kepada semua pihak, utamanya kepada para dosen agar arahnya dapat dipahami dengan jelas.

Selain hal tersebut di atas, dalam melahirkan SDM ekonomi syariah yang unggul, IBS sangat memperhatikan cita-citanya, yakni alumninya harus siap pakai jika bekerja di perbankan. Jadi kalau ada pelatihan di perbankan tersebut hanya pelatihan penyesuaian 
gaya perusahaan untuk alumni IBS. Ringkasnya, harus siap pakai, meskipun harus bisa menyesuaikan karena yang ada di luar sana belum tentu sama yang ada di sini. Untuk mewujudkan hal ini tentunya mahasiswa IBS harus dibekali dengan manajerial skill, yakni hard skill dan soft skill.

Hard skill yang diberikan IBS kepada mereka yaitu praktek di mini bank, yakni mahasiswa mempraktekkan di posisi mana dia nanti ditugaskan. Soft skill, juga praktek di mini bank, yaitu mereka diajari cara mengambil keputusan. Jadi, praktek hard skill dan soft skill di mini bank itu adalah simulasi.

Adapun gambaran mengenai hasil pengembangan SDM di IBS, dapat merujuk kepada testimoni alumni yang telah bekerja di Lembaga Keuangan Syariah. Menurut asesor seperti yang diungkap Mujahid Quraisy (hasil wawancara, 2012), ternyata alumni IBS jauh lebih baik dari pada alumni-alumni perguruan tinggi lain. Artinya, mereka betul-betul memahami dan menguasai dengan baik tentang hal-hal yang terkait dengan keuangan dan perbankan syariah.

Secara spesifik menurut Mujahid (hasil wawancara, 2012), sesungguhnya mereka diarahkan untuk menjadi SDM yang profesional. Jadi, yang dipikirkan adalah bagaimana menjadikan mereka profesional perbankan syariah yang memiliki kepribadian yang baik, kepribadian islami tentunya. Usaha yang dilakukannya ini cukup berhasil karena LKS, seperti Bank Muamalat, BMT, dan lain-lain sering menawari alumni-alumni IBS pekerjaan. Bahkan di antara mereka, ada yang menempati posisi manajer. Hal ini tidak terlepas dari manajerial skill, yakni hard skill dan soft skill, yang diberikan IBS kepada mereka.

Hasil survei internal IBS pada bulan Februari 2012, alumni IBS tahun 2011 yang menyatakan telah bekerja secara tetap 70\%, lanjut studi S2 10\%, dan berstatus menunggu 20\%. Mereka yang telah bekerja, 60\% berkarier di lembaga keuangan dan perbankan, sementara sisanya sebanyak $40 \%$ berstatus PNS, wiraswasta dan karyawan swasta non keuangan (Tim IBS, 2012: 01). Ini adalah testimoni dan kontribusi nyata yang dipersembahkan oleh para alumni IBS kepada almamaternya, masyarakat, bangsa dan negara. 
Rofiul Wahyudi alumni IBS tahun 2011, melakukan penelitian tentang kinerja almuni IBS yang telah bekerja di lembaga keuangan syariah (Bank Syariah, BPR Syariah, BMT dan Asuransi Syariah). Aspek yang diteliti adalah kemampuan teknis, kemampuan konseptual dan kemampuan hubungan interpersonal alumni IBS. Hasil penelitiannya menunjukkan bahwa penilaian pengguna terhadap kemampuan teknis, kemampuan konseptual dan kemampuan hubungan interpersonal alumni IBS dalam bekerja di lembaga keuangan syariah adalah sedang (Wahyudi, 2011). Artinya alumni IBS dapat bekerja dengan baik di lembaga keuangan syariah, meskipun harus diakui bahwa mereka masih memiliki berbagai macam kekurangan. Namun mereka sudah menunjukan hasil yang baik sebagai alumni IBS.

Samino Setiawan (hasil wawancara, 2012), alumni IBS tahun 2000, kariernya diawali sebagai pengusaha di bidang percetakan pada tahun 2005, aktif sebagai trainer perbankan syariah dan konsultan bisnis, memberikan suatu testimoni bahwa setelah ia tamat dari IBS, hal yang membuat cakrawala berfikirnya benar-benar berubah yaitu materi kuliah bernama "Total Management Sunnatullah" atau dalam bahasa tehniknya dikenal dengan istilah pendekatan sistem. Materi kuliah ini sangat membantu pemikirannya untuk bisa berkreativitas. Secara pribadi, Samino akan terus mengembangkan kreativitasnya selama melihat ada peluang A, B, C, D. Ia akan berusaha agar bisa menangkap peluang itu semua. Tentunya dalam hal ini tidak sekedar mencari materi saja tapi lebih kepada ingin memaksimalkan potensi yang ia miliki.

Sebagai alumni IBS, ketika terjun ke tengah-tengah masyarakat di pikiran, penglihatan, dan pengamatan Samino dkk (hasil wawancara, 2012). banyak melihat praktek-praktek transaksi ekonomi yang menyimpang dari syariah. Oleh karena itu, praktek yang tidak benar menurutnya, harus dapat dihilangkan sedikit demi sedikit tentunya dengan jalan edukasi kepada masyarakat.

Lain halnya dengan Suryati (Tim IBS, 2012: 03), alumni IBS tahun 2000 ini, kariernya diawali sebagai staf marketing di BMT alIkhlas pada tahun 2003. Kini ia telah dipercaya menjabat Direktur Utama BMT al-Ikhlas. Ia merupakan pilar tangguh yang berperan besar dalam mengembangkan BMT al-Ikhlas dengan aset Rp. 60 
milyar dan 6 kantor cabang. Kiat strategi yang diterapkan dalam menakodai BMT al-Ikhlas adalah sikap disiplin dan kerja keras.

Hal yang sama juga diungkapkan oleh Kayyisul Fakhri (Tim IBS, 2012: 03), alumni IBS tahun 2008. Kini ia bekerja di Bank Muamalat Jakarta sebagai Support Departement Muamalat Institute. Kayyisul menyatakan bahwa siap berjuang menjadi profesional syariah yang handal. Demikian juga yang disampaikan oleh Dwi Anugrah Hadi wibowo (Tim IBS, 2012: 03), alumni IBS tahun 2007. Setahun setelah tamat dari IBS, ia bekerja di BSM Jakarta sampai sekarang sebagai Marketing Support. Dalam dua tahun terakhir ini, loyalitasnya di BSM Jakarta ditunjukan dengan prestasi kerja dan karya yang gemilang. Tahun 2009 ditetapkan sebagai Sharia Funding Executive (SFE) terbaik, tahun 2011 ditetapkan sebagai juara 1 Innovation award kategori Operasional Kantor Cabang "Penerapan Sistem Monitoring SFE". Kemudian Ana Rahimah (Tim IBS, 2012: 03), alumni IBS tahun 2011, saat ini bekerja di bank BRI Cabang Kuala Kapuas sebagai Sekretaris, juga menegaskan bahwa setelah menyelesaikan kuliah di IBS banyak tawaran dan pilihan bekerja di sektor keuangan baik di bank maupun di non bank.

Selain testimoni dan kontribusi alumni di atas, masih banyak alumni-alumni lainnya yang melakukan hal yang sama, namun tidak bisa disebut satu persatu. Hal yang terpenting adalah bahwa alumni IBS adalah alumni yang produktif. Artinya, IBS berhasil mengembangkan SDM ekonomi syariah yang dibutuhkan pasar, khususnya industri perbankan syariah di Indonesia.

\section{Kesimpulan}

Berdasarkan uraian tersebut di atas, maka dapat ditarik kesimpulan sebagai berikut: Pertama, SDM ekonomi syariah yang dibutuhkan oleh industri perbankan syariah di Indonesia sekarang ini, adalah SDM dengan kemampuan lebih dari sekedar bankir. SDM haruslah SDM yang multi dimensi, yang memiliki kompetensi lintas keilmuan. Ia harus memiliki kompetensi sebagai seorang ahli investasi, sekaligus ahli keuangan dan perbankan, beretika serta memahami sharia compliancy. Pemenuhan SDM dengan kompetensi lengkap seperti ini harus dilakukan, baik secara kualitatif maupun kuantitatif, 
melalui proses rekruitmen dan pelatihan.

Kedua, hal yang tersirat dalam visi IBS adalah melahirkan SDM ekonomi syariah yang unggul, dan untuk mewujudkan hal ini mereka didesain dengan kompetensi yang dibutuhkan oleh industri perbankan syariah. Dengan demikian, SDM yang dikembangkan di IBS didesain dengan empat kompetensi utama supaya mereka bisa unggul dalam memasuki industri perbankan syariah setelah tamat. Keempat kompetensi utama yang dimaksud, yaitu: kompetensi inti, perilaku, fungsional dan manajerial. Keempat kompetensi inilah yang dibutuhkan oleh industri perbankan syariah di Indonesia sekarang.

\section{Daftar Pustaka}

Amalia, Euis. 2009. Keadilan Distributuf dalam Ekonomi Islam: Peran LKM dan UKM, Jakarta: PT. RajaGrafindo.

dkk., 2010. "Peta Potensi SDM Ekonomi Islam pada PTAI dan PTU: Analisis Kurikulum, Model Pembelajaran dan Hubungannya dengan Kebutuhan SDM pada Industri Keuangan Syariah di Indonesia”, Hasil Riset Perbankan Syariah-BI, Tahap II.

Anonymous. 2009. "Menggodok Kurikulum-Menyiapkan SDM Handal”, Artikel, Majalah Sharing, Edisi April.

Darma, Surya. 2002. "Pengembangan SDM Berbasis Kompetensi". Majalah Usahawan, No. 01 TH XXXI Januari.

Direktorat Perbankan Syariah-BI. 2012. "Jaringan Kantor Perbankan Syariah”, Statistik Perbankan Syariah, Bank Indonesia, September.

. 2012. "Sekilas Perbankan Syariah", Dokumen, Direktorat Perbankan Syariah-BI, Dikutip dari www.bi.go.id, Diakses Tanggal 10 Nopember.

. 2012. "SDM Multi Dimensi Untuk iB", Dokumen, Direktorat Perbankan Syariah-BI, Dikutip dari www.bi.go.id, Diakses Tanggal 10 Nopember.

IDB (Islamic Development Bank). 2008. Annual Report IDB Tahun 2008, Jeddah: IDB.

Farisal. 2010. "Pengembangan Kompetensi SDM Perbankan Syariah 
Melalui Corporate University", Hasil Penelitian, STEI SEBI Depok Jawa Barat.

Fauzi, Yuslam. 2009. "Perkembangan, Peluang dan Tantangan Perbankan Syariah di Indonesia”, Makalah, Seminar: Ada Apa dengan RUU Perbankan Syariah, LPEB-PKB Jakarta.

Fleischhauer, Kai-Joseph. 2007. "A Review of Human Capital Theory:

Microeconomics", Discussion Paper, Department of Economics, University of St. Gallen, No. 2007-01, Januari.

Green, Diana (Ed.). 2000. What is Quality in Higher Education: Concept, Policy and Practice, London: SRHE an Open University Press.

IBS Yogyakarta. 2012. "Join Us to be Profesional and Shariah Banking", Welcome To ISB STEI Yogyakarta, Dikutip dari: http://www.stei-yog.ac.id, Diakses pada Tanggal 16 April.

Kertajaya, Hermawan. 2009. The Sustainable Marketing Enterprices, Jakarta: MarkPlus.

Lieras, Miquel Palacios. 2004. Investing in Human Capital: A Capital Markets Approach to Student Funding, Cambridge, UK: Cambridge University Press.

Nazir, Habib, dan Muhammad Hasanuddin. 2004. Ensiklopedi Ekonomi dan Perbankan Syariah, Bandung: Kaki Langit.

Noor, Muhibbin. 2011. "Pengembangan Prodi Ekonomi Islam di Fakultas Syariah IAIN Wali Songo", Artikel Ekonomi Islam, Dikutip dari www.iainwalisongo.ac.id, Diakses pada tanggal 25 Desember.

Perbankan Syariah BI. 2010. Statistik Perbankan Syariah Bank Indonesia, Jakarta: BI, Bulan September.

Purwanda, Eka. 2012. dengan judul "Model Pengembangan SDM Industri Perbankan Syariah di Indonesia: Kajian Analitis pada Skenario Stedy State". Hasil Penelitian, Dipresentasikan pada Forum Riset Perbankan Syariah V, Makassar 26-27 Juni.

Tilaar, H.A.R. 2009. Beberapa Agenda Reformasi Pendidikan Nasional dalam Persfektif Abad 21, Magelang: Indonesia Tera.

Tim BPS BI. 2009. Outlook Perbankan Syariah Tahun 2009, Jakarta: Bank Indonesia. 
Tim IBS STEI Yogyakarta. 2012. "Buku Panduan Akademik Tahun 2012", IBS STEI Yogyakarta.

. 2011 "Kondisi Alumni ISB Yogyakarta Tahun 2011", Hasil Survei, Survei Internal Islamic Banking School Yogyakarta. 2012. "No Boby Perfecr But Team Can Be", IBS-HotNews, Vol. 06, XXIII/04.

. 2012 "Profil Alumni", Dokumentasi Internal, IBS STEI Yogyakarta.

. 2012. "STEI Yogyakarta: Semangat Baru Akreditasi Baru", IBS-HotNews, Vol. 06, XXIII/04.

Tim Peneliti FE UI. 2003. "Kondisi dan Kebutuhan SDM pada Perbankan Syariah Indonesia", Hasil Penelitian, Fakultas Ekonomi Universitas Indonesia.

Wahyudi, Rofiul. 2011. "Penilaian Pengguna terhadap Kinerja Lulusan IBS STEI Yogyakarta pada Lembaga Keuangan Syariah”, Skripsi, IBS STEI Yogyakarta, Tidak Diterbitkan. 